\title{
The Need for Professionally Oriented ESL Instruction in the United States
}

THOMAS N. HUCKIN

Carnegie-Mellon University

\section{LESLIE A. OLSEN}

University of Michigan

\begin{abstract}
Increasing numbers of foreign students are coming to the United States for university-level studies. Most go on to professional careers where English is needed for sophisticated and complex uses. Unfortunately, these students and professionals seldom receive English language training adequate for this purpose, either in school or on the job. Using engineering as a case in point, this article argues that there is a growing need for professionally oriented ESL instruction in American colleges, universities, and companies. Such instruction should combine aspects of both ESL and ESP in what is here called "generalized ESP." Two illustrations of this approach-technical communication courses for university students and troubleshooting for technical professionals-are discussed.
\end{abstract}

Since World War II, increasing numbers of foreign students (FSs) have been coming to the United States to pursue university studies. FS enrollments during this time have grown at an average annual rate of more than $10 \%$; at last count (1982-83), it stood at 336,990 (Scully 1983). The American Council of Education's (ACE) Committee on Foreign Students and International Policy, as recently as two years ago, predicted enrollments of more than one million FSs in American colleges and universities by the early 1990s (Scully 1981). Although the rate of enrollment has slowed since then, it still appears likely that the one million mark will be reached before the turn of the century.

Most of these students have studied English for many years and have received satisfactory scores on the TOEFL, Michigan Test, or some other test of English proficiency. Nevertheless, their English is often quite weak, especially in the productive skills. Most FSa are 
aware of this, of course, and genuinely desire to work on their English. Indeed, according to many students we have spoken with and according to several informal surveys we have seen, one of the principal reasons FSs give for coming to the United States in the first place is the opportunity it presents for improving their English. This being the case, one might expect that FSs would sign up in large numbers for ESL courses. The fact is, however, that relatively few of them do. Only about $4 \%$ of the 336,990 FSs presently in the United States are enrolled in intensive English courses (Scully 1983), and probably even fewer are taking non-intensive courses.

Although academic advisers and FSs themselves usually cite monetary and time constraints as reasons for such low ESL enrollments, the real reason seems to be that most FSs simply do not need to take any ESL courses, at least not for academic survival. In many academic disciplines, especially the more technical ones, FSs can get by with relatively meager English language skills. We have encountered many FSs at some of the country's best engineering schools, for example, who have had great difficulty expressing themselves either in speech or in writing, yet who have been passing all of their technical courses without difficulty. Their respective skills, in particular lecture comprehension and reading, although not well developed, have been sufficient to get them through. And their academic program advisers, knowing this to be the case, have done little to encourage them to work on their English.

But what happens to these students after they receive their diplomas and start out on their careers? If they go on to work in an English-speaking organization, as many do, they will be expected to display a solid command of English on the job. Good communication skills are virtually essential for success in any organization, even in highly technical fields. Professional employees who cannot communicate effectively will almost certainly find their careers seriously handicapped. Thus, FSs at American universities should be encouraged to work on their English not just because it is the medium of instruction but also because it will be the medium of communication if they go to work for an English-speaking company. A level of English proficiency that is good enough for coursework may well not be good enough for professional work.

The purpose of this article is threefold: 1) to argue that more and more FSs and non-native English-speaking (NNS) professionals in the United States will be needing ESL instruction at advanced levels, 2) to demonstrate that for many such learners this instruction should be professionally oriented, and 3) to suggest some ways in which this might be accomplished, both in American universities and in American companies. To illustrate these points, we will focus 
on the single largest subgroup of FSs and NNS professionals in the United States-those in engineering.

\section{HIGH FOREIGN ENROLLMENTS IN TECHNICAL CURRICULA}

As shown in Table 1, the largest numbers of foreign students in the United States-more than $50 \%$ of the total declaring majors-are studying science and technology (Institute for International Education 1978, 1980, 1982, 1984). This has been true for a number of years. More importantly, the number of foreign-born science and technology students is rising rapidly, from about 120,630 in 1976-77 to 178,120 in $1982-83 .{ }^{1}$ At this rate, it should rise to more than a quarter of a million by the early 1990s.

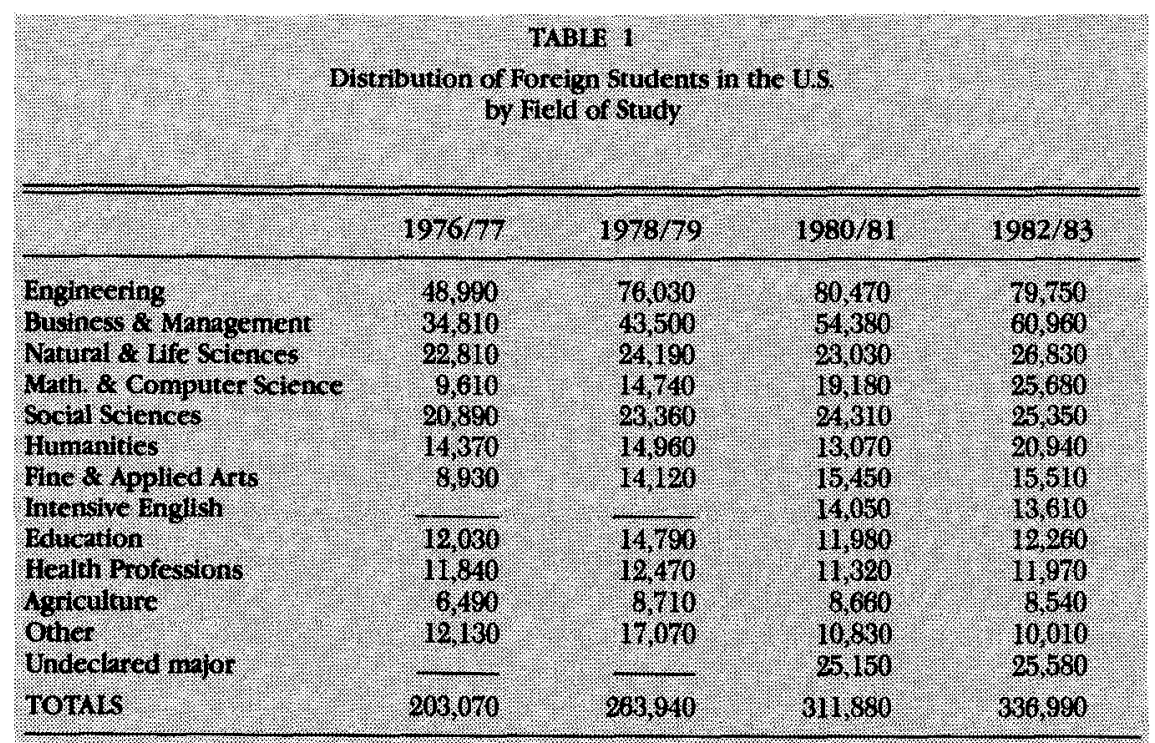

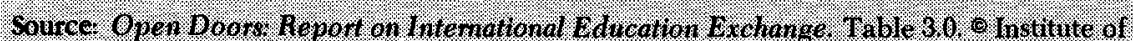

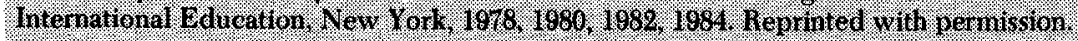

The single most popular field of study for FSs in the United States is, and always has been, engineering. In 1982-83 (as can be seen in Table 1), 79,750 FSs were studying engineering or some engineeringrelated field. In 1980-81. the most recent year for which data is available, foreign enrollment in American engineering graduate

1 These figures represent the totals for the following categories: engineering, natural and life sciences, math and computer science, social sciences, health professions, and agriculture. No doubt many other science and technology students can be found in other fields, but we have not included these. 
programs was $35.5 \%$ overall, with the percentage of foreign Ph.D. candidates rising to $44.8 \%$ (Geils 1982) and the percentage of foreign students receiving engineering doctorates rising to 50\% (TESOL Newsletter 1983). At the University of Michigan's College of Engineering, FSs presently comprise more than $50 \%$ of the total graduate enrollment and are expected to increase in number for at least the next few years. Indeed, with the economies of the world becoming more and more technological and at the same time increasingly interdependent, there is good reason to believe that FS enrollments at every American school of engineering will continue to rise noticeably. Richard Berendzen, Chairman of the ACE Committee on Foreign Students and International Policy, has stated that "by the end of the century $40-50 \%$ of all students in the U.S. in some hightechnology subjects will be from foreign lands" (U.S. News\& World Report, October 5, 1981).

\section{EXTENSIVE USE OF ENGLISH}

\section{AMONG NNS TECHNICAL PROFESSIONALS}

Although it is difficult to find comprehensive data on the subject, our impression is that most foreign-born technical students in the United States goon to professional careers in organizations where a good command of English is very important, if not essential. One major locus of such careers, of course, is the United States: in a 1978 study, the United States Labor Department found that one out of every three FSs took jobs in the United States after graduation (Greer 1983). In one giant American corporation we know of, twothirds of all of the research professionals hired in recent years have been NNSs educated at American universities. This hiring pattern should come as no surprise, since more and more American companies are recruiting technical graduates at the masters and doctoral levels and, as we indicated above, about half of such graduates are foreign-born.

As for the many foreign students who return home after studying in the United States, they too will probably need to use English reasonably frequently and with some sophistication. Since English is increasingly becoming the international language of science and technology, most technical professionals around the world need to know it, at least to some extent. Consider Japan, for example. Dwight Stevenson, a colleague who has done extensive consulting in Japan, has this to say about the use of English by technical professionals there:

I found that in Japanese industries, English technical discourse is remarkably common-it is in fact the basic technical language. Engineers,

TESOL QUARTERLY 
technicians, managers routinely communicate among themselves as well as with the outside world in written technical English. Engineers working at Sony Corporation, for example, write monthly progress reports in English. Instructions, manuals, feasibility studies, specifications, test reports, and technical articles are written in English even when they are not intended for circulation in English-speaking countries. [A sampled group of approximately seventy] on-the-job engineers and managers working in Japanese corporations . . . write, on the average, one document in English every second or third day. Many of them write in English much more than that. Of this same group of seventy, I asked "In what language do you usually write?" They answered: In English only, 44\%; in Japanese only, 22\%; in both, 34\% (Stevenson, in press).

Stevenson concludes that "English is used by technical professionals in Japan with astonishing frequency and in a remarkable variety of technical communication situations" (Stevenson, in press).

\section{COMMUNICATION SKILLS REQUIRED OF TECHNICAL PROFESSIONALS}

If large numbers of FSs in the United States will ultimately be using English primarily for technical/professional purposes, then teachers of these students-especially university-level ESL teachers-should have a clear idea of what kinds of English they are likely to need. The purpose of this section, therefore, is to paint a general picture of these needs. Although this picture is based on studies which have considered mainly native speakers (NSs) exclusively in American contexts, we feel that it depicts reasonably well the way communication takes place within any modern technological organization.

Technical professionals are fundamentally problem solvers. They are trained in school and ultimately hired into a job to solve technical problems. But technical problems in the real world, unlike those in the academic world, do not exist in isolation. Rather, they are invariably part of some broader organizational problem. Technical professionals who work in large, complex organizations must understand this larger context. Whatever solutions they propose for technical problems must be consonant with solutions proposed for broader organizational problems. This requires that technical professionals communicate regularly with various people from various backgrounds for various purposes. In particular, they must often translate their technical knowledge into forms that can be understood by corporate executives, sales personnel, customers, and other non-technical people. If they aspire to move up the ladder into management, as many do, it becomes all the more important that they be able to communicate easily with a range of people. Indeed, 
it is safe to say that no employees of an organization, no matter how technically brilliant they might be, will be given managerial responsibility without first demonstrating good communication skills. Since most technical students plan to work for some organization after graduation, many of them ultimately at some management level, it makes sense to acquaint them with these facts while they are still in school and indeed to use these facts for pedagogical purposes, as we shall suggest later.

Figure 1 depicts schematically how technical professionals are expected to function as communicators within organizations. Before they can solve a given problem, they must first understand the broader nature of the problem as the organization sees it-how it bears on the organization's goals and how it is affected by constraints the organization is operating under. This represents a major departure from the kind of problem solving that they are trained to do in school, where technical problems are neatly defined and the nontechnical complicating factors are minimized or eliminated altogether. And the difficulty is compounded for many NNS technical professionals by the fact that these non-technical concerns are often not spelled out in any formal written description but are instead expressed indirectly in briefings or impromptu meetings, in conversation, over the telephone, or in informal written memos or notes. Technical professionals need to know enough general (non-technical) English to understand such accounts of organizational problems, even when they are presented in colloquial or highly elliptical language.

Once technical professionals actually become engaged in a technical investigation, they initiate their technical problem solving by gathering appropriate information. This is usually not done as systematically as one might suppose. A large National Science Foundation research project, which surveyed 15,000 practicing engineers in industry and government, found that the large majority of these engineers gathered technical information via "corridor communication," that is, via very informal and local channels (Shuchman 1981). Instead of using the company's computerized data base or technical library, these engineers talked to colleagues, supervisors, and company "know-it-alIs," often in informal settings such as during coffee breaks or over lunch. Such conversations may have considerable technical content, but they also contain a good deal of ordinary conversational English. So here too, even in the heart of the professional's technical work, arises the need to know general idiomatic English and to use it effectively in a social setting.

When the technical investigation is concluded, the professional is expected to communicate the results of the investigation to 
]

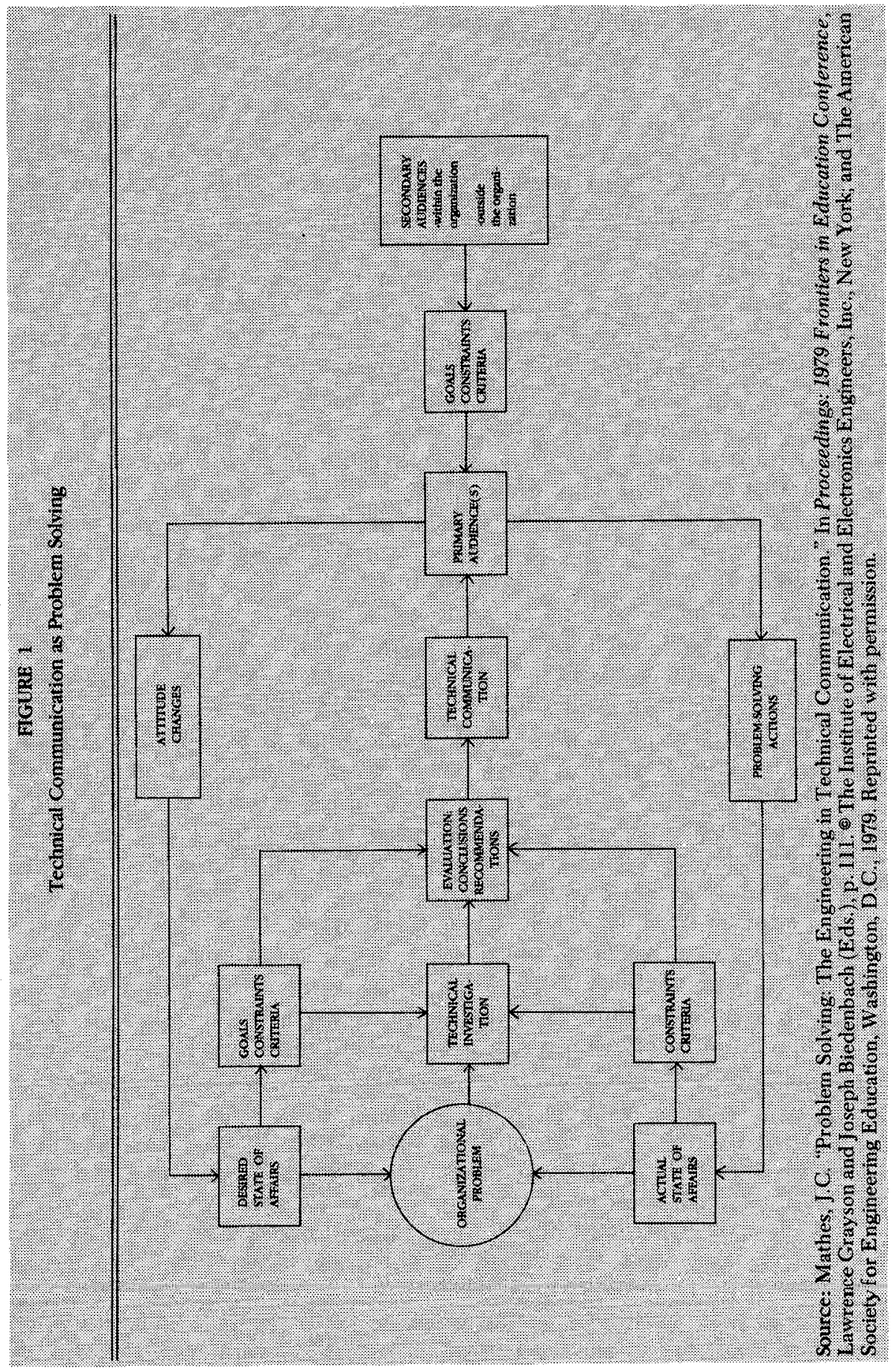

PROFESSIONALLY ORIENTED ESL INSTRUCTION 
appropriate audiences, who can then initiate appropriate actions to solve the organizational problem. Such reporting is usually done in writing (although it is also often supplemented by an oral presentation of some kind), and it occurs frequently. Indeed, one recent survey of 109 college-educated technical and professional employees found that they devoted fully $29 \%$ of their work time, on the average, to writing (Faigley and Miller 1982:560).

The audiences these writers write for, as noted, for example, by Mathes and Stevenson (1976) and by Odell, Goswami, Herrington, and Quick (1983), are not at all like audiences students are accustomed to in school. In school settings, the audience usually consists of one reader (the teacher) whom the writer knows relatively well. This reader usually reads carefully, trying hard to figure out what the writer is saying and has learned in order to assign a fair grade. This reader usually reads the entire assignment, is usually interested in the subject, usually knows more about the subject than the writer, and often can fill in missing information or see where an unclear argument is going. Since the purpose of school writing is to display knowledge (rather than to inform), the teacher/reader usually looks at every detail to see if there is evidence of such knowledge.

In contrast, the technical professional in a real world setting has a far more complex audience to deal with. First, this real world "audience often includes many people with different backgrounds and with different, even conflicting, needs. Thus, it is not feasible to have just one reader in mind when preparing a report. Second, real world audiences frequently have little knowledge of or interest in a communicator's subject and often pay attention to only parts of a report. Some audiences, on the other hand, include experts in the field who have great interest in the subject and are likely to study the report in detail. Third, whereas academic audiences often want to see as many supporting details as possible, a real world audience is often more interested in generalizations. In fact, some audiences do not want details at all, since details just confuse their grasp of the subject, Finally, as demonstrated by Mintzberg (1973), most real world audiences, especially middle- and high-level managers-the most important audiences, read and listen under the worst possible conditions: they have many pressing things on their minds, they are constantly interrupted, and they must read quickly just to get through their mail each day.

To deal with such audiences, technical professionals must learn to use effective rhetorical strategies. They must present not only the results of their investigations but also their interpretation of these results as they pertain to the organizational problem, and especially their recommendations for future action. Often such interpretations 
and recommendations are not straightforward but rather depend on compromises and trade-offs which require careful explanation. Thus, technical professionals should be prepared to produce complex arguments involving multiple conditions and qualifications and, depending on their audience, to do so in either technical or non-technical language. Furthermore, they should be prepared to present this information orally as well as in writing. Oral communication is often faster than written communication, and it facilitates immediate feedback and clarification. Consequently, as noted, for example, in Schiff (1980), much important communication in industry is carried on through conversations and small-group discussions.

In short, technical professionals should be able to formulate sound arguments, produce appropriate generalizations, emphasize main points-and do so concisely, yet clearly, in both writing and speech. Given all of these demands which are placed on the technical professional as a communicator, it comes as no surprise to find 1) that technical professionals need to have a large variety of high-level communication skills, 2) that their ability to communicate is critically important to job success, and 3) that even many native Englishspeaking American technical professionals lack adequate communication skills.

For example, a survey of 4,057 practicing engineers ranked the importance of academic subjects most needed for job success. The results, given in Table 2, show that communication skills rank above any other type of skill, capturing 5 of the 9 "most-needed" categories (Middendorf 1980). These include technical writing (2), public speaking (4), working with individuals (6), working with groups (7), and talking with people (9). In contrast, technical skills ranked toward the bottom of the list.

A second recent survey of 367 practicing engineers ranks the types of communication skills needed on the job and ranks them on a scale of 1 to 7, where 1 means "least important" and 7 means "most important" (Schiff 1980). The results, presented in Table 3, show clearly that:

1. technical professionals should develop strong speaking and writing skills

2. technical professionals should learn to communicate in a wide variety of forms

3. technical professionals should learn to communicate complex technical concepts to non-technical as well as to technical people.

A third survey (Kimel and Monsees 1979) asked practicing engineers to rate the importance of different areas of competence for 


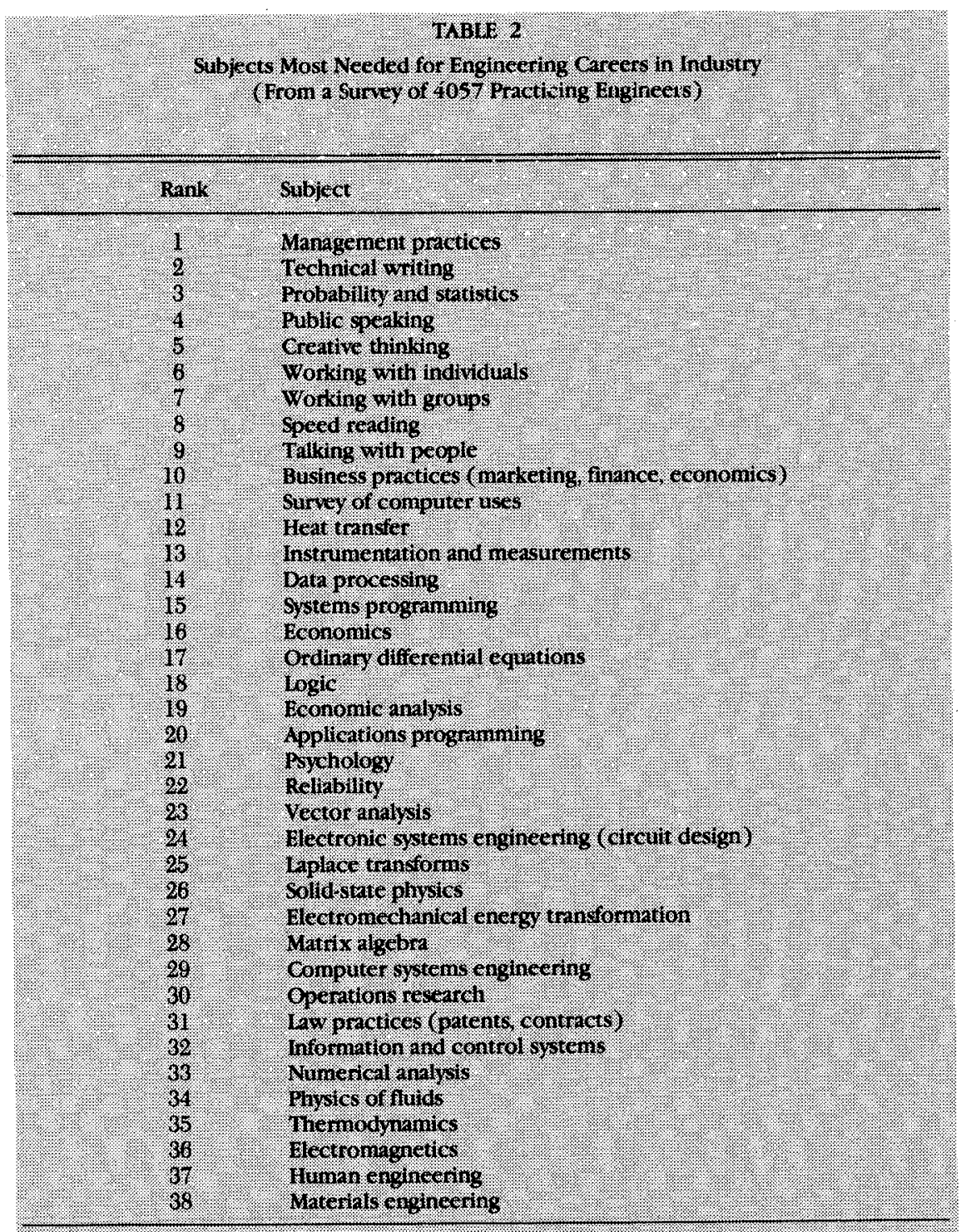

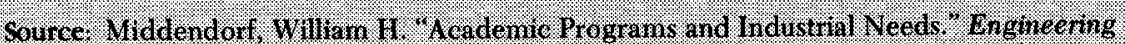

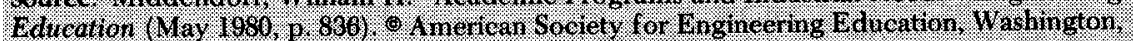
1D.C. 1980. Reprinted with permission.

professional practice in their particular field of engineering. The same engineers were then asked how they judged the capabilities of recent college graduates in those areas. The most important area of competence turned out to be writing and speaking. Unfortunately, it was also the area in which recent graduates were felt to be least 
T. BI B 3

Rarik Order of Job Impontance Responses:

(From a Surver of 367 Praeticing Eigineers)

( 1 = least importan, $t=$ nost important)

\begin{tabular}{|c|c|c|c|}
\hline Ranil. & Communcaton Skill & Nean & $\begin{array}{l}\text { Standard } \\
\text { Deviation }\end{array}$ \\
\hline 1 & One-to one talls with technically Sophisticated & 50891 & 13109 \\
\hline 2. & Writing using graphs, chants, and/or other Hustrat & 5.3955 & 17141 \\
\hline 3. & Project proposils (witten) & 5.3824 & $1816 \%$ \\
\hline 4. & $\begin{array}{l}\text { Participation in a small group or commitee made } \\
\text { only techinically sophisticated members (oral) }\end{array}$ & $\mathbf{5 . 2 6 9 4}$ & 1738 \\
\hline 5 & Instructions for completing a technical process (Writien) & 52444 & 1.0332 \\
\hline 6 & One-to bne talks with nontechnical personnel & 5.0718 & 1.9065 \\
\hline 7 & rroject progress reports (witten) & 50608 & 1.6301 \\
\hline 8 & rroject preposal presentarions (oral) & 5.0587 & 1.9787 \\
\hline 9 & Wring communicating technical intormation to & 4.9157 & 1.9898 \\
\hline 10 & Oral presentations using graplis, chirts, and/or other nids & 40109 & 1.9623 \\
\hline 11. & Technical description of a piece of hardware ( Nritue & 48687 & 1.8790 \\
\hline 12 & Menorinda & 4.8169. & 1.7176 \\
\hline 13 & $\begin{array}{l}\text { Shor reports (less thinh ten pages typeonititen } \\
\text { doublespaced). }\end{array}$ & 4.7967 & 1.8507 \\
\hline 14 & Wring conmunircating techitical information to & 4.758 & $2.13 \%$ \\
\hline 15 & Iroject teasibility studies (Writen) & 4.7124 & 10303 \\
\hline 16. & Project progress report presentations (oral) & 4.6667 & 1.9277 \\
\hline 17. & $\begin{array}{l}\text { Participation in a small group or conmitted incl } \\
\text { non technical nembers (omal). }\end{array}$ & 4.6639 & 1.9608 \\
\hline 18 & Business leners. & 4.6257 & 1.8858 \\
\hline 19 & Telephione reports & 4.5838 & 1.19682 \\
\hline 20. & Prolect teasibility stady presentations (oral) & 4.4258 & 20780 \\
\hline 21: & Fom comptetion & 42844. & 18847 \\
\hline 22. & Iromal specehes to technically soghisticated audiences & 4.0452 & 22108 \\
\hline 23 & Writing ha collabortion with one or more collengues & 40313 & 20175 \\
\hline 24 & Wibortory reports (witien) & 4.0184 & 21800 \\
\hline & 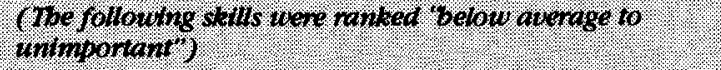 & & \\
\hline 25 & 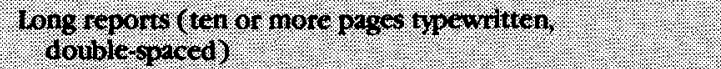 & 3.8249 & 2.2120 \\
\hline 26. & Formal speteches to nontechnical abdiences: & 3.5869 & 22020 \\
\hline 27 & Writing reguining library rescarch & 32062 & 28728 \\
\hline 28 & Abstrects/summaries of others' witing & 28864 & 109910 \\
\hline 29. & Aructes submined to professionil Jeurnals. & 28074 & 21499 \\
\hline 30 & Reports subnitted to professional soevetres (Witten) & 27224 & $2082 \%$ \\
\hline
\end{tabular}

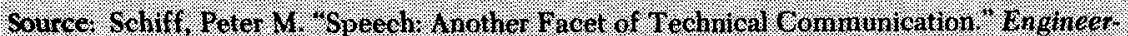
ing Edication (November 1080 p. 1810. 0 American Sociaty for Engineering Edication. Washingron, D.C., 1980 . Reprinted with permission.

skilled. For example, in the civil engineering poll (Table 4), 223 out of 232 professional civil engineers rated writing and speaking as 
$\square$

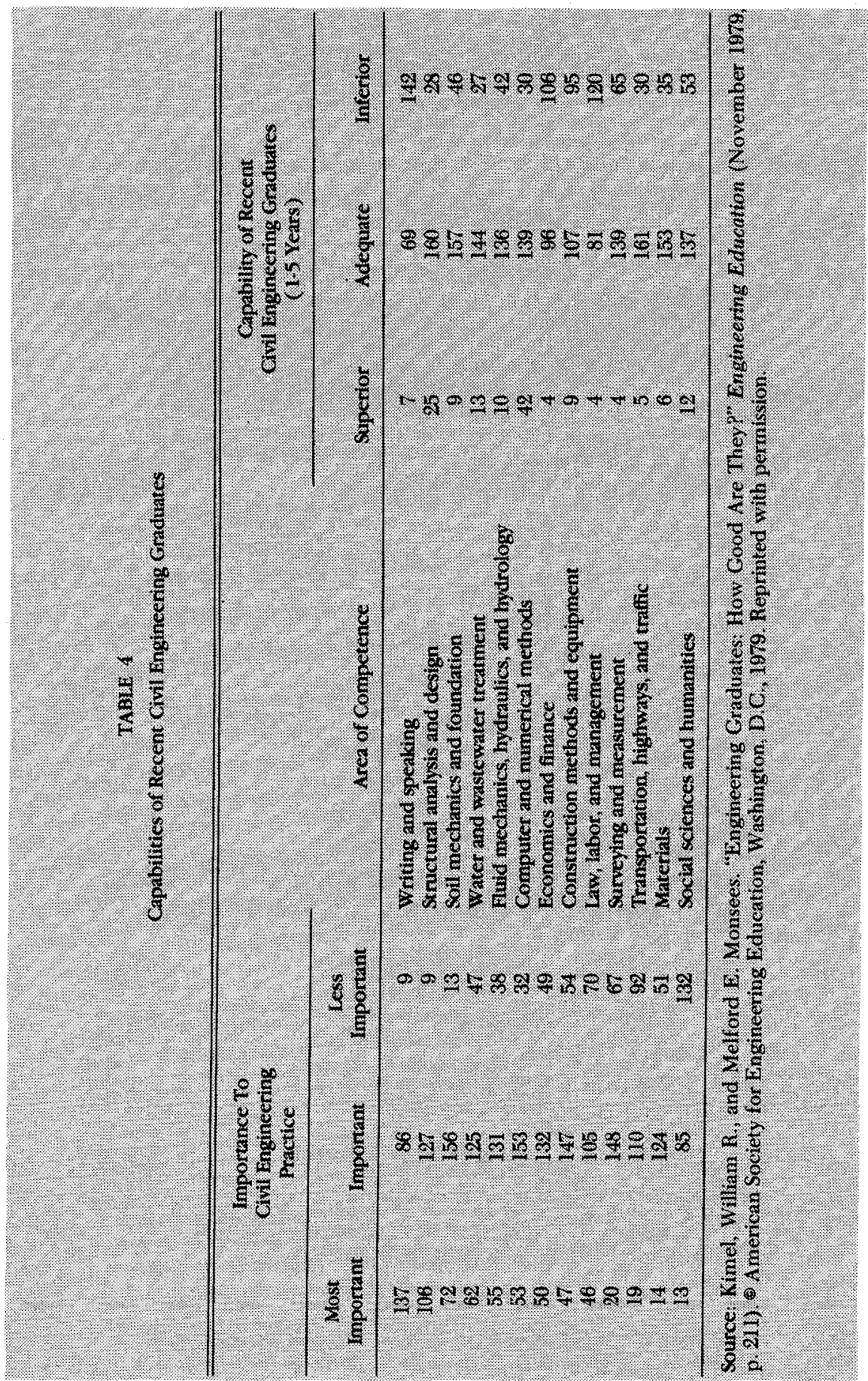


either "most important" or "important" to civil engineering practice-a higher rating than any of the more technical areas of competence, such as structural analysis and design or soil mechanics and foundation. Yet, an overwhelming majority of these respondents (142 of 218) felt that recent civil engineering graduates were inferior in their writing and speaking abilities.

A more specific indication of where technical professionals are felt to be weak in their communication skills is provided in two surveys, by Macintosh (1967) and by Davis (1977). Macintosh asked 182 senior managers in science and industry to express their complaints about the technical writing they read; Davis asked 245 distinguished engineers, whose names were drawn at random from Engineers of Distinction (the equivalent of "Who's Who" in engineering), to suggest topics that should be included in a technical writing course. The respondents to these surveys-all from real world industrial or governmental settings-felt that technical professionals often lack the general vocabulary and stylistic skills needed to produce clear, concise sentences; that they often fail to analyze the situation, uses, and audiences for a given piece of writing and thus fail to address some of the most important issues involved; that they often cannot organize their writing so as to give proper emphasis to main points; and that they often do not make clear the step-by-step logical reasoning and coherence that non-specialists need in order to understand various explanations and arguments (see Table 5 for the Davis data). Although these two surveys looked only at writing, we have found that technical professionals have similar problems with oral communication.

\section{IMPLEMENTING PROFESSIONALLY ORIENTED ESL}

What is the common thread running through all of these complaints? It is the widespread inability of technical professionals-NSs and NNSs alike - to communicate with people outside their field of specialization. Such non-specialists are included in many of the most important audiences a technical professional has: company executives, customers, managers, government officials, even some colleagues or supervisors. Yet technical professionals seldom get much training in how to deal with such audiences, either in school or on the job.

The problem is of course compounded for NNSs, who have a narrower range of linguistic and sociolinguistic resources to draw on (in English) than do NSs. They could remedy some of these shortcomings by taking general ESL courses, but most FSs-especially those in technical fields-fail to perceive the relevance of 


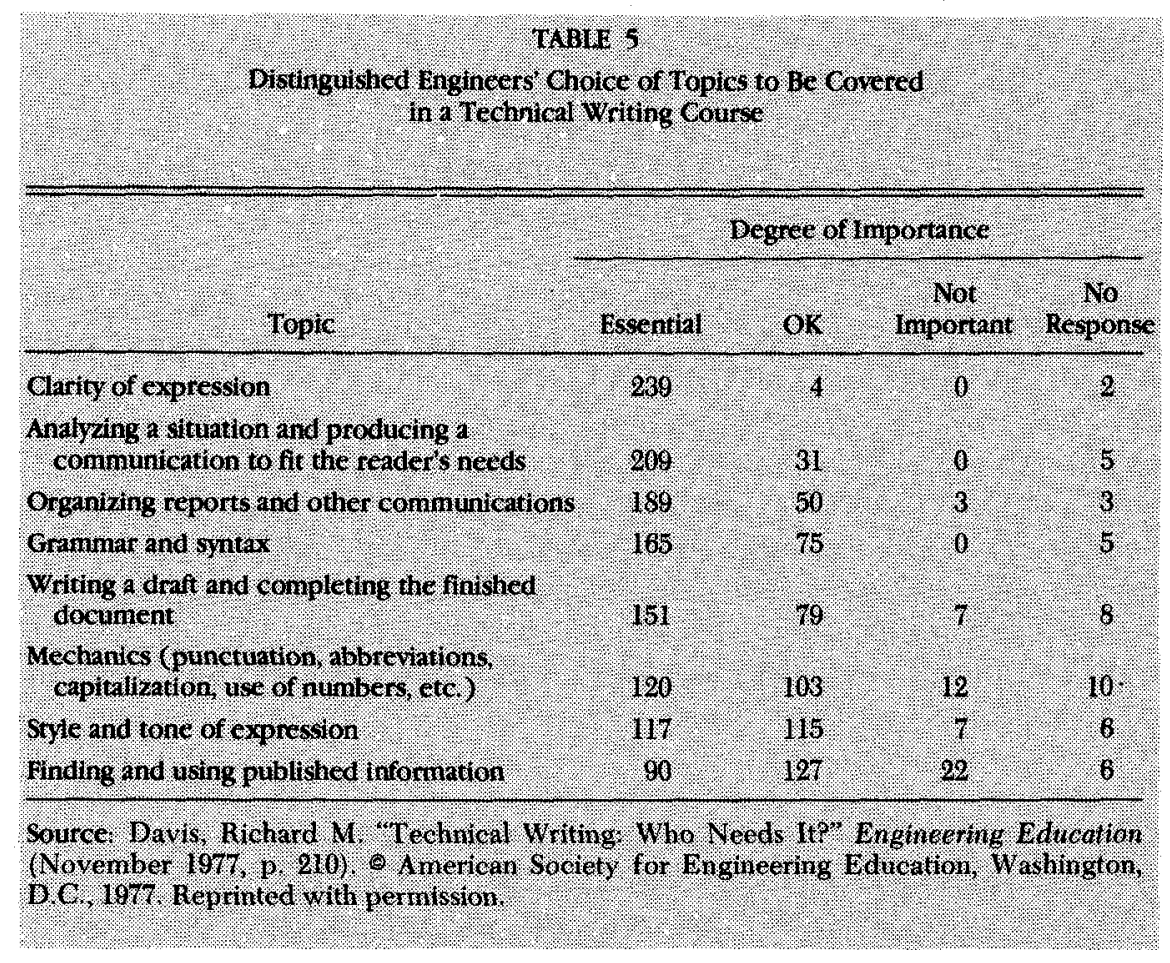

general ESL to either their academic or their professional careers and thus avoid taking these courses. Courses in English for Special Purposes (ESP) appeal more directly to students' interests, but they typically concentrate on lecture comprehension, note taking, using the library, writing examination papers, and other study skills which are of little value in the more complex world of professional work.

The solution to this problem, we feel, lies in a generalized form of ESP instruction which we will call professionally oriented ESL. Professionally oriented ESL, when taught to students who are already in,. or soon to be engaged in, professional careers, directly addresses a specific, perceived need, As such, it qualifies as ESP and carries the motivating power that all ESP courses, in principle, have. But it is broader than traditional ESP instruction, focusing as it does on features of general English and general communication. It can be used to organize a formal class, bringing together students from a cluster of related disciplines-different fields of engineering, for example-and giving them training in communicating across those disciplines. Or it can be used for one-on-one tutoring, allowing the instructor to comfortably play a non-specialist's (i.e., "managerial") role with regard to the content of the communication, but a specialist's role with regard to its form.

There are two obvious clienteles for such instruction: 1) students

TESOL QUARTERLY 
soon to graduate from the university and begin a professional career, and 2) professionals already engaged in a career.

\section{Technical Communication Courses for University Students}

Professionally oriented ESL fits very well into technical communication courses offered to senior undergraduate and graduate students soon to enter the job market. ${ }^{2}$ The express purpose of such courses is to train students to be effective communicators as technical professionals. This "real world" focus makes these courses quite unlike most university courses and helps explain why many students who are nearing graduation freely elect to take them. In fact, technical communication courses are rapidly increasing in popularity, from enrollments of 25,000 students nationwide in 1968 to over a quarter million in 1982 (Houp and Pears all 1984), and are now commonplace at American colleges and universities.

Technical communication courses typically address "the kinds of communication problems described above. They teach, speaking and writing skills, including vocabulary, style, rhetoric, organization, argumentation, audience analysis, and mechanics. They acquaint students with a wide variety of written and spoken genres: reports, memos, proposals, letters, journal articles, instructions, briefings, the use of visual aids, and so on. Most importantly, by drawing together students from different disciplines and having them communicate with each other, these courses teach students how to communicate complex technical concepts to non-specialist readers and listeners.

This instruction is at least as useful for NNSs as it is for NSs, but it must be presented in a form that takes the NNSs' special linguistic and cultural problems into consideration. Unfortunately, the vast majority of technical communication instructors that we have met over the years do not have any ESL training or teaching experience and simply do not know how to deal with such problems. In such circumstances, the NNS often feels intimidated, unable to compete with the NSs in the class. On the other hand, it has been our experience that when the technical communication teacher is able to take into account the special problems that NNSs have and is able to give them the help that they need, they usually respond enthusiastically and sometimes even outperform the NS students.

Thus, technical communication courses present good opportunities for ESL teachers to practice professionally oriented ESL. Unfortunately, most ESL teachers of our acquaintance feel quite reluctant to step into a technical communication classroom. They

2 These have traditionally been called "technical writing" courses, but the name is a misnomer because oral presentations, group discussions, and other forms of oral communication are now an important part of most of these courses.

PROFESSIONALLY ORIENTED ESL INSTRUCTION 
seem to fear that without specific technical training they will not be able to understand what it is that their students are trying to communicate to them. One of us (Huckin), coming from a liberal arts background, recalls feeling the same way when he first started out. But it is important to bear in mind that, as in the real world, the burden is really on the specialist (i.e., the student, in this case) to make his or her information comprehensible to the non-specialist. The technical communication teacher, like the corporate executive, does not have to have much technical knowledge. ${ }^{3}$ Furthermore, one discovers that even in a class made up entirely of technical students, these students may represent many different fields of study and may have almost as much trouble communicating with each other as they do with the teacher. In this respect, the teacher is not much more isolated than any one student. Finally, it is a common experience in technical communication courses that everyone "teaches" everyone else, including the students teaching the teacher. Indeed, this is part of the pleasure of teaching such courses. Unlike most academic courses, each student in a technical communication course has specialized knowledge that the teacher, and other students in the class, do not have, And, in such cases, the student takes great pride in playing teacher, This change in roles is beneficial in many ways: it gives practice in genuine communication, it enhances class dynamics, and, last but not least, the knowledge that is passed on does "rub off." In fact, we have probably learned more about engineering from our students over the years than from any other source.

Thus, teaching technical communication courses should not bean intimidating prospect for ESL teachers, especially if they have the opportunity to first get some training. Teacher-training programs can be found around the country, mainly in the form of one- or two-week summer workshops or seminars. Although most are not designed specifically for ESL teachers, they nonetheless welcome ESL teachers and are devoting more and more attention to techniques for teaching NNSs. Training can also be accomplished in a less formal way by offering one's services as an ESL aide to a regular technical communication teacher, This approach gives the ESL teacher valuable on-the-job experience and at the same time benefits the teacher and the NNSs in the class.

Of course, technical communication courses vary greatly in quality and effectiveness. The better ones all follow a communicative 3 This is not to say, of course, that technical communication teachers would not benefit from
having a basic conceptual knowledge of the methodologies used in the disciplines in which their students specialize, just that it does not have to be a deep, detailed knowledge. 
approach by engaging the students in simulated "real world" activities of some sort. As argued in Taylor (1983), for example, such an approach promotes student motivation and learning and also facilitates practice of the four language skills. Setting up such a course is relatively easy when the students are senior undergraduates or graduate students (or working professionals), since such students can be asked to simulate or reconstruct communicative situations from their own real world experience with summer jobs or internships, and then do writing and speaking assignments based on these situations. This works reasonably well with American students, but sometimes not so well with foreign students. Because of visa restrictions in the United States and sociocultural patterns in their home countries, foreign students even at the graduate level sometimes have had no working experience outside the university.

For these reasons, a more elaborated version of this approach usually works better, namely, the case method (see, for example, Barton and Barton [1981], Flower [1981], and Piotrowski [1982] and the references cited therein). The case method creates a realistic microworld in which students can assume simulated identities and interact in genuine communication. An instructor who is willing to invest the necessary time and energy can use case studies to create an entire simulated company within which each student is assigned a role, preferably a role which allows them to draw on their technical training; the instructor, meanwhile, can comfortably assume a nonspecialist, managerial role. Students are given tasks (or encouraged to generate tasks of their own) which require them to exchange memos, letters, phone calls; to submit project proposals and progress reports; to give briefings and formal oral presentations; to have committee meetings; to work together on long-term writing projects. As in the real world, much of this communication should be cast in a form which is understandable to non-specialists, including not only the manager (instructor) but also the other students in the class who happen not to be in the same discipline. For help in learning how to do this, and also in learning the genre conventions associated with these activities, students can refer to an appropriate technical communication handbook (for example, Houp and Pearsall 1984, Lannon 1982, or Olsen and Huckin 1983 for NSs; Huckin and Olsen 1983 for NNSs). The instructor, in addition to playing a managerial role, can play an editor's role and can enjoy being "on the student's side" as a helpful consultant rather than being the traditional lecturer, taskmaster, and grader. 


\section{Troubleshooting for Technical Professionals}

Industry is another natural site for professionally oriented ESL. As noted earlier, there are many NNS technical professionals in American companies. Unlike students, industry professionals know how important communication skills are to career success. They are often aware of their language problems and are eager to remedy them. But they generally do not want a standard university-style course in either technical communication or ESL. As Pearson (1983) points out, industry professionals have highly specific learning objectives compared to university students. Instead of a global approach, these learners typically prefer specific remedies for specific problems, ranging from communication tasks (e. g., how to initiate a telephone conversation, how to give an oral presentation, how to write business letters) to points of grammar and pronunciation (e.g., how to use articles, how to pronounce the word wheel).

The ESL specialist working in industry should therefore be a troubleshooter, identifying communication problems and recommending specific solutions. Such troubleshooting in industry can be very satisfying for both teacher and learner because it often yields quick results. Unfortunately, many ESL teachers are reluctant to work with technical professionals in industry for fear of being overwhelmed by a deluge of technical concepts and terms. While it is true that technical professionals are more knowledgeable about their field than students are, their communication problems do not arise within their field so much as outside of it. In other words, they are more likely to have trouble with English pronunciation, idiomatic usage, conversational pragmatics, and spelling than they are with the technical language of their specialty. They are more likely to have trouble communicating with non-specialists than with fellow specialists. In short, what they are most likely to need from the English teacher is help with aspects of general English.

The best teaching approach to take with such students, in our experience, is a highly individualized one. Working professionals are very impatient with any instruction which is not of direct help to them and, as Pearson (1983) points out, they have a more delicate self-image. Individualized instruction (e.g., one-on-one tutoring) addresses" these two problems most effectively so long as the instructor takes a "reactive" stance and avoids dominating the teacher-student relationship. Students should be encouraged to identify and diagnose their own communication problems, and they should be allowed to select their own "class texts" (their own written reports or oral presentations, perhaps, if that is where the communication problems occur). The teacher's role is to respond to language problems as they arise, as in the "Conference Method," popular in 
English composition pedagogy, ${ }^{4}$ or in the Counseling-Learning/ Community Language Learning method of Charles Curran (1976). Computer-assisted instruction, because it is so interactive, also promises to be useful someday in such settings. For example, if computer programs were available that would allow users to enter their own text into a word processor and have it immediately critiqued for grammatical and stylistic correctness, industry professionals would make great use of them. Such programs are currently being developed, but it may be a long time before they reach the market in a usable form.

One of the most fruitful applications of the individualized approach with NNS technical professionals, in our experience, is with speech problems. We have encountered many highly trained NNS professionals in industry whose major communication problems involved talking to or with non-technical people, both in formal and informal settings. Like all professionals, they have to engage in all of the oral communication activities discussed earlier (and included in Table 3). They have to make themselves understood on the spot without help from anyone else, and this makes whatever speech problems they have very noticeable (writing problems, by contrast, although they abound among NNS technical professionals, can sometimes be covered up by extra editing). One of us (Huckin) has long been working as a speech consultant for NNS research scientists and engineers in one of the largest corporations in the United States. These professionals must give frequent oral presentations and briefings to managerial audiences, yet many of them-despite having lived in the United States for ten years or more-have serious problems with segmental pronunciation, intonation, speech rhythm, idiomatic usage, turn taking, paraphrasing, and other aspects of oral communication. After several false starts involving conventional language lab tapes and small classes, it was found that only intensive, personal, one-on-one tutoring worked.

\section{CONCLUSION}

The approach described above is grounded in the assumption that students learn best when they are most motivated to do so. Their motivation is highest, we feel, when they perceive the learning to be of great usefulness to them, especially in the near future. Although many FSs in the United States still have years of schooling ahead of them and therefore want help only with academic skills (mainly

4 Dawe and Dornan (1981) describes this approach in detail; although written for NSs, it can be adapted to ESL uses. (Editor's Note: Melanie Schneider's review of this text [TESOL Qsrarterly, Volume 17, Number 3, September 1983] evaluates it from an ESL perspective.) 
reading and listening), many other FSs are close to graduating and are therefore more concerned with developing real world communication skills, especially the productive skills of speaking and writing. These FSs, as well as NNS professionals already employed, are professionally oriented; accordingly, they should be given professionally oriented ESL instruction.

The approach we propose is clearly a type of ESP instruction, tailored to the needs and interests of a particular group of users. In the case at hand, we have focused on engineers and have described two applications-ESL-augmented technical communication courses for university students and individualized troubleshooting for industry professionals-that we feeI are particularly suitable for this group. But this should not obscure the fact that what we are advocating is a "generalized" form of ESP, unlike the more narrowly defined ESP normally associated with courses in English for Academic Purposes or study skills. Just as real world, professional communication is more wide-ranging and "general" than academic communication, ESL instruction for professionally oriented students should also be wide-ranging and "general": it should help students develop a broad repertoire of language skills in order to be able to communicate with a broad range of audiences. ${ }^{5}$ This approach, of course, will not appeal to everyone; in particular, it will probably not appeal to students who are years away from graduation (e. g., in intensive courses or in EAP courses). However, for career-oriented foreign students and professionals-who comprise a significant yet generally overlooked segment of the NNS population in the United States, we have found that it is more motivating and more useful than the standard approaches currently being used in most ESL or ESP programs.

\section{ACKNOWLEDGMENTS}

This article is a revised version of a paper presented at the 1983 TESOL Convention in Toronto. We wish to thank Barry Taylor, TESOL Quarterly Editor, for his many helpful editorial comments and suggestions.

5 For additional discussion in support of this generalized approach to ESP, see Williams (1978), Hutchinson and Waters (1980), and Crofts (1981). 


\section{THE AUTHORS}

Thomas N. Huckin is Associate Professor of Linguistics and Rhetoric in the Department of English at Carnegie-Mellon University, where, beginning next year, he will direct the university's new ESL program. He previously taught ESL at the University of Washington and at the University of Michigan. Presently, he is in Brazil as a Fulbright Lecturer.

Leslie A. Olsen is an Associate Professor of Technical Communication in the College of Engineering at the University of Michigan. She has consulted for a variety of universities, industries, and governmental agencies and is the co-author of Principles of Communication for Science and Technology and English for Science and Technology: A Handbook for Non-Native Speakers, both published by McGraw-Hill (1983).

\section{REFERENCES}

Barton, Ben, and Marthalee Barton. 1981. The case method: bridging the gap between engineering student and professional. In Courses, components, and exercises in technical communication, Dwight Stevenson (Ed.), 22-33. Urbana, Illinois: National Council of Teachers of English.

Crofts, J. N. 1981. Subjects and objects in ESP teaching materials. In English for academic and technical purposes: studies in honor of Louis Trimble, Larry Selinker, Elaine Tarone, and Victor Hanzeli (Eds.), 146153. Rowley, Massachusetts: Newbury House.

Curran, Charles A. 1976. Counseling-learning in second languages. Apple River, Illinois: Apple River Press.

Davis, Richard. 1977. Technical writing: who needs it? Engineering Education 68 (2: November): 209-211.

Dawe, Charles, and Edward Dornan. 1981. One-to-one: resources for conference-centered writing. Boston: Little, Brown.

Faigley, Lester, and Thomas Miller. 1982. What we learn from writing on the job. College English 44 (6):557-569.

Flower, Linda. 1981. Communication strategy in professional writing: teaching a rhetorical case. In Courses, components, and exercises in technical communication, Dwight Stevenson (Ed.), 34-46. Urbana, Illinois: National Council of Teachers of English.

Ceils, John. 1982. The faculty shortage: a review of the 1981 AAES/ASEE survey. Engineering Education 73 (2: November): 152.

Greer, William. 1983. Foreign students: boon or a threat? The New York Times 132 (45630: 27 March): 72-73.

Houp, Kenneth; and Thomas Pearsall, 1984. Reporting technical information. Fifth Edition. Beverly Hills, California: Glencoe Press.

Huckin, Thomas, and Leslie Olsen. 1983. English for science and technology: a handbook for nonnative speakers. New York: McGraw-Hill.

Hutchinson, Tom, and Alan Waters. 1980. ESP at the crossroads. English for Specific Purposes 36:1-6. Corvallis, Oregon: Oregon State University.

Institute for International Education. 1978, 1980, 1982, 1984. Open doors: report on international education exchange. New York: Institute for International Education.

PROFESSIONALLY ORIENTED ESL INSTRUCTION 
Kimel, William, and Melford Monsees. 1979. Engineering graduates: how good are they? Engineering Education 70 (2: November): 210-212.

Lannon, John. 1982, Technical writing. Second Edition. Boston: Little, Brown.

Macintosh, Fred. 1967. How good is our product? Paper presented at the annual meeting of the Conference on College Composition and Communication, Louisville, Kentucky, April 8, 1967.

Mathes, J. C. 1979. Problem solving: the engineering in technical communication. In Proceedings: 1979 Frontiers in Education Conference, Lawrence Grayson and Joseph Biedenbach (Eds. ), 109-112. New York: The Institute of Electrical and Electronics Engineers, Inc., and Washington, D. C.: The American Society for Engineering Education.

Mathes, J. C., and Dwight Stevenson. 1976. Designing technical reports. Indianapolis: Bobbs-Merrill.

Middendorf, William. 1980. Academic programs and industrial needs. Engineering Education 70 (8: May): 835-837.

Mintzberg, Henry. 1973. The nature of managerial work. New York: Harper and Row.

Odell, Lee, Dixie Goswami, Anne Herrington, and Doris Quick. 1983. Studying writing in non-academic settings. In New essays in technical and scientific communication: research, theory, practice, Paul Anderson, John Brockmann, Carolyn Miller (Eds.), 17-40. Farmingdale, New York: Baywood.

Olsen, Leslie, and Thomas Huckin. 1983. Principles of communication for science and technology. New York: McGraw-Hill.

Pearson, Sheryl. 1983. The challenge of Mai Chung: teaching technical writing to the foreign-born professional in industry. TESOL Quarterly 17 (3): 383-400.

Piotrowski, Maryann. 1982. Business as usual: using the case method to teach ESL to executives. TESOL Quarterly 16 (2): 229-238.

Schiff, Peter. 1980. Speech: another facet of technical communication. Engineering Education 70 (2: November): 180-181.

Scully, Malcolm. 1981. One million foreign students at U.S. colleges, triple present number, seen likely by 1990, Chronicle of Higher Education 23 (8: October 21): 1.

Scully, Malcolm. 1983. Foreign students' increase slackens to 3.3 pet. in year. Chronicle of Higher Education 27 (11: November 9): 21.

Shuchman, Hedvah. 1981. Information transfer in engineering. Glastonbury, Connecticut: The Futures Group.

Stevenson, Dwight. In press. Audience analysis across cultures. Journal of Technical Writing and Communication.

Taylor, Barry. 1983. Teaching ESL: incorporating a communicative, student-centered component. TESOL Quarterly 17 (1): 69-88.

TESOL Newsletter. 1983. Largest number ever of foreign students. TESOL Newsletter 27 (1: February): 10.

U.S. News $\mathcal{E}$ World Report. 1981. Foreign students in U.S.-problem and opportunity. U.S. News \& World Report (October 5, 1981): 66.

Williams, Ray. 1978. EST—is it on the right track? MALS Journal: English for Specific Purposes. University of Birmingham, England.

TESOL QUARTERLY 